\title{
HUBUNGAN ANTARA PEMAHAMAN NILAI PANCASILA SILA PERSATUAN INDONESIA DAN SIKAP NASIONALISME PESERTA DIDIK KELAS XI IPS SMA NEGERI 1 ANGKOLA SELATAN
}

\author{
Yusmiati, Shofia Ulfa \\ FKIP Universitas Muhammadiyah Tapanuli Selatan
}

\begin{abstract}
Abstrak
Hubungan antara pemahaman nilai Pancasila sila Persatuan Indonesia dan sikap Nasionalisma peserta didik kelas XI IPS SMA Negeri Angkola Selatan. Rumusan masalah dalam penelitian ini adalah Apakah ada hubungan antara Pemahaman Nilai Pancasila Sila Persatuan Indonesia dan Sikap Nasionalisme Peserta Didik Kelas XI IPS SMA Negeri 1 Angkola Selatan. Sedangkan tujuan penelitian ini adalah Untuk membahas hubungan pemahaman nilai pancasila sila persatuan Indonesia dan sikap nasionalisme peserta didik kelas XI IPS SMA Negeri 1 Angkola Selatan. Metode penelitian yang digunakan adalah penelitian Asosiatif, yaitu untuk mengetahui hubungan anatara dua variabel atau lebih, dengan pendekatan penelitian lapangan (field research) dan penelitian kepustakaan (library research).Adapun rumus yang digunakan untuk menguji hipotesis dalam penelitian ini adalah rumus korelasi Product Moment oleh Pearson. Dari hasil perhitungan korelasi maka diperoleh $r_{x y}=0,998$. Jika angka indek korelasi tersebut dikorelasikan dengan " $r$ " tabel product moment maka didapat bahwa pada taraf kesalahan $5 \%$ diperoleh 0,325 dan pada taraf kesalahan $1 \%$ diperoleh 0,418. Dengan demikian dapat diketahui bahwa nilai $r_{x y}$ lebih besar daripada $r$ tabel yakni 0,998>0,325 dan 0,998>0,418. Hipotesis yang diajukan dapat diterima kebenarannya. Bahwa Ada Hubungan Antara Pemahaman Nilai Pancasila Sila Persatuan Indonesia Dan Sikap Nasionalisme Peserta Didik Kelas XI IPS SMA Negeri 1 Angkola Selatan.
\end{abstract}

Kata Kunci: Nilai Pancasila sila Persatuan Indonesia dan sikap nasionalisme

*Correspondence Address : yusmiati @um-tapsel.ac.id DOI : 10.31604/jips.v6i2.2019.208-213

(C) 2019 Fakultas Keguruan \& Ilmu Pendidikan UM-Tapanuli Selatan 


\section{A. Pendahuluan}

Pendidikan secara umum dapat diartikan sebagai usaha-usaha untuk menumbuhkan potensi-potensi pembawaan baik jasmani maupun rohani agar berfungsi dan mampu melaksanakan tugas-tugas kehidupan serta budaya. Usaha tersebut dijalankan dengan menanamkan nilai-nilai budaya serta mewariskan/menyampaikan karya budaya yang ada pada generasi muda, untuk dihargai dan dikembangkan dalam hidup dan kehidupannya

Seiring berkembangnya zaman, rasa nasionalisme bangsa terasa kian memudar. Hal ini dapat dibuktikan dari berbagai sikap dalam memaknai berbagai hal penting bagi negara Indonesia. Contoh sederhana yang menggambarkan betapa kecilnya rasa nasionalisme, diantaranya: Pada saat upacara bendera, terlihat masih banyak peserta didik yang tidak memaknai arti dari upacara tersebut.

Dari hal kecil tersebut terkandung nilai pembelajaran yang sangat tinggi yaitu untuk merebut kemerdekaan, para pahlawan berjuang mati-matian . Upacara merupakan suatu wadah untuk menghormati dan menghargai para pahlawan yang telah berjuang keras untuk kemerdekaan negara Republik Indonesia dari tangan para penjajah. Upacara bendera juga mengajak peserta didik untuk berjiwa nasionalis. Upacara bendera harus terus dilakukan disekolah-sekolah. Kehadirannya dalam mengikuti upacara harus terus semakin ditingkatkan , disempurnakan agar anak bangsa menghargai pentingnya disiplin, menghargai jasa para pahlawannya, dan yang paling penting mengajak peserta didik untuk senantiasa bangga akan bangsa dan negaranya.

Peserta didiktidak mengikuti upacara dengan khidmad.Pada peringatan hari-hari besar nasional, seperti Sumpah Pemuda, hari Kesaktian Pancasila, dan hari besar nasional lainnya hanya dimaknai sebagai serermonial dan hiburan saja tanpa menumbuhkan rasa nasionalisme dan patriotisme dalam benak peserta didik.

Peserta didik juga lebih tertarik terhadap produk impor dibandingkan dengan produk buatan dalam negerikarena banyaknya produk luar negeri (sepertiMc Donald, Coca Cola, Pizza Hut, dll.) yang membanjiri Indonesia. Dengan hilangnya rasa cinta terhadap produk dalam negeri menunjukan gejala berkurangnya rasa nasionalisme masyarakat kita terhadap bangsa Indonesia. Dan peserta didik lebih banyak mencampurkan bahasa 
asing dengan bahasa Indonesia untuk meningkatkan gengsi. Kurangnya kesadaran masyarakat pada umumnya untuk memasang bendera di depan rumah, kantor atau pertokoan dengan berbagai macam alasan entah benderanya sudah sobek atau tidak punya tiang bendera, malas, cuaca buruk, dan lain-lain.

Rasa nasionalisme semakin menurun, adanya modernisasi dan individualistis. Kurangnya kecintaan kita terhadap produk dalam negeri dan merasa bangga kalau bisa memakai produk luar negeri. Rasa nasionalisme bangsa pada saat ini muncul bila ada suatu faktor pendorong, seperti kasus pengklaiman beberapa kebudayan dan pulau-pulau kecil Indonesia seperti Sipadan, Ligitan, serta Ambalat oleh Malaysia beberapa waktu yang lalu. Namun rasa nasionalisme pun kembali berkurang seiring dengan meredanya konflik tersebut.

Guru merupakan seorang yang bertanggung jawab mencerdaskan peserta didiknya. Pribadi peserta didik yang cakap, diharapkan ada pada diri setiap peserta didik. Tidak ada seorang guru yang mengharapkan peserta didiknya menjadi sampah masyarakat. Untuk itulah guru dengan penuh dedikasi dan loyalitas berusaha membimbing dan membina peserta didik agar di masa mendatang menjadi orang yang berguna bagi nusa dan bangsa. Dengan cara menanamkan sikap-sikap yang dapat memupuk rasa nasionalisme peserta didik dan menyadari betapa pentingnya rasa cinta terhadap tanah air negara Republik Indonesia melalui pemahaman nilai-nilai yang terkandung dalam pancasila, khusus nya sila persatuan Indonesia.

Guru merupakan seorang yang bertanggung jawab mencerdaskan peserta didiknya. Pribadi peserta didik yang cakap, diharapkan ada pada diri setiap peserta didik. Tidak ada seorang guru yang mengharapkan peserta didiknya menjadi sampah masyarakat. Untuk itulah guru dengan penuh dedikasi dan loyalitas berusaha membimbing dan membina peserta didik agar di masa mendatang menjadi orang yang berguna bagi nusa dan bangsa. Dengan cara menanamkan sikap-sikap yang dapat memupuk rasa nasionalisme peserta didik dan menyadari betapa pentingnya rasa cinta terhadap tanah air melalui pemahaman nilai-nilai yang terkandung dalam pancasila, khusus nya sila persatuan Indonesia.

Peserta didik merupakan pelajar yang bisa dikatakan masih terkait oleh 
aturan-aturan yang masih dibatasi kebebasannya. Peserta didik dapat di katakan seorang atau sekelompok orang yang menuntut ilmu di bangku sekolah.Atau dengan kata lain, peserta didik adalah orang yang menuntut ilmu sedalam mungkin, baik yang rela mengeluarkan segala jerih payahnya dengan tujuan untuk menempuh masadepan yang cerah dengan catatan peserta didik itu tidak menyia-nyiakan kesempatan yang diberikan.

Pemahaman nilai-nilai Pancasila merupakan salah satu program mata pelajara Pendidikan Pancasila dan Kewargannegaraan. Nilai-nilai Pancasila diambil dan digali dari bangsa Indonesia sendiri. Mata pelajaran Pendidikan Pancasila dan Kewaganegaraan sebagai mata pelajaran wajib diberikan di tingkat pendidikan termasuk pendidikan SMA.

Berdasarkan pengamatan serta wawancara pada guru yang dilakukan oleh penulis di SMA Negeri 1 Angkola Selatan terdapat bukti bahwa rendahnya pemahaman nilai pancasila sila persatuan Indonesia peserta didik dapat dilihat dari sikap gotong royong. Peserta didik masih kurang menyadari sehingga kedisiplinan yang ada belum nampak dengan tidak adanya perilaku bergotong royong. Dampaknya, dari kurangnya pemahaman akan nilai persatuan, peserta didik belum sukarela membantu dalam segala hal yang ada di sekolah. Hal tersebut dapat terlihat dengan kurang adanya perilaku gotong royong, tolong-menolong, bahu membahu, saling membantu antara peserta didik yang satu dengan peserta didik yang lain.

Rendahnya sikap nasionalisme peserta didik dapat dilihat dari masih ada kecenderungan sikap peserta didik yang tidak antusias dalam mengikuti upacara bendera di setiap hari senin,tidak tepat waktu atau terlambat datang ke sekolah, dan berkurangnya rasa cinta terhadap tanah air.

\section{B. Hasil dan Pembahasan}

Pokok permasalahan dalam penelitian ini adalah : Apakah ada hubungan antara pemahaman nilai Pancasila sila Persatuan Indonesia dan sikap nasionalisme peserta didik kelas XI IPS SMA Negeri Angkola Selatan?. Setelah data terkumpul selanjutnya dianalisa dengan menggunakan rumus Product momen. Dari perhitungan korelasi maka diperoleh nilai $r$ hitung 0,998 .

Nillai $r$ hitung kemudian dibandingkan dengan nilai $r$ tabel, nilai $r$ tabel 0,325 pada taraf kesalahan $5 \%$, dan 0,418 pada taraf kesalahan $1 \%$. 
Maka nilai $r$ hitung lebih besar dari nilai $r$ tabel yaiitu dimana nilai $r$ hitung lebih besar dari nilai $r$ tabel yaitu $0,998>$ 0,418 atau $0,998>0,325$..Sesaui dengan dasar pengambilan keputusan bahwa: Terima Ha (hipotesa alternatif) jika nilai $r$ hitung labih besar dari nilai $r$ tabel, dan terima $\mathrm{HO}$ (hipotesa 0 ) jika nilai $r$ hitung lebih kecil dari nilai $r$ tabel.

Berdasrkan perhitangan dimana $r$ hitung lebih besar dari nilai $r$ tabel, maka Ha diterima yang berbunyi bahwa "Ada hubungan antara pemahaman nilai Pancasila sila Persatuan Indonesia dan sikap nasionalisme peserta didik kelas XI IPS SMA Negeri Angkola Selatan. Sedangkan HO ditolak yang berbunyi :Tidak ada hubungan antara pemahaman nilai Pancasila sila Persatuan Indonesia dan sikap nasionalisme peserta didik kelas XI IPS SMA Negeri Angkola Selatn. Berdasarkan perhitungan tersebut dapat disimpilkan bahwa hipotesis yang penulis ajukan diterima kebenarannya.

Pemahaman nilai pancasila sila persatuan Indonesia dan sikap nasionalisme peserta didik merupakan hal penting yang tidak bisa dianggap begitu saja. Adanya kesadaran akan kecintaan terhadap tanah air membuktikan generasi penerus bangsa yang kuat dan berkarakter. Dengan adanya pemahaman peserta didik terhadap nilai Pancasila sila Persatuan Indonesia maka akan timbul sikap nasoinalisme, cinta tanah air, bangga sebagai bangsa Indonesia, mencintai produksi dalam negeri.

\section{Kesimpulan}

Berdasarkan data yang diperoleh dan selanjutnya perhitungan koefisien korelasi, maka diperoleh hasil $r$ hitung $=$ 0,998 hasil ini kemudian dibandingkan dengan $r$ tabel dimana $r$ hitung lebih besar dari $r$ tabel yaitu 0,998>0,325 pada taraf kesalahan $5 \%$ dan 0,998> 0,418 pada taraf kesalahan $1 \%$ maka dapat dikatakan bahwa ada hubungan antara pemahaman nilai pancasila sila persatuan Indonesia dan sikap nasionalisme peserta didik kelas XI IPS SMA Negeri 1 Angkola Selatan.

\section{Daftar Pustaka}

Ahmadi, Abu. 2007. Psikologi Sosial. Jakarta; Rineka Cipta.

Anas, Sudjono. 2004. Metodologi Penelitian Pendidikan. Jakarta: Bumi Aksara

Arikunto, Suharsimi. 2009. Dasar-dasar Evaluasi Pendidikan. Jakarta: Bumi Aksara.

Asrori, Mohammad. 2009. Psikologi Pembelajaran. Bandung: CV Wacana Prima

Azwar, Saefuddin. 2005. Sikap Manusia Teori dan Pengukurannya. Yogyakarta: Pustaka Pelajar. 
Bahri, Syaiful. 2007. Metodologi Penelitian Pendidikan. Jakarta: Bumi Aksara

Darmodiharjo, Darji. 1983. Pancasila Dalam Beberapa Perspektif. Jakarta : Aries Lima

Dimyatidan Mudjiono. 2006. Belajar dan Pembelajaran. Jakarta: Rinek aCipta

Hamid K, Abdul, dkk. 2013. Pendidikan Pancasila Dan Kewarganegaraan. Bandung : Pustaka Setia.

Kaelan. 2000. Pendidikan Pancasila. Yogyakarta: Paradigma

KartonoKartini. 2002. Pengantar Metologi Research Social. Bandung: Alumni.

Nawawi, Hadari. 2000. Metode Penelitian. Jakarta: Gramedi

Nazir, Muhammad. 2005. Metode Penelitian. Jakarta: PT Ghalia Indonesia.

Notonagoro. 1984. Pancasila Secara Ilmiah Dan Populer. Jakarta : BinaAksara.

Panndonyo, S.Toto. 1985. Ulasan Terhadap Beberapa Ketentuan Undang-Undang Dasar. Jogyakarta : Liberty.

Purwanto, Ngalim. 2000. Psikologi Pendidikan. Bandung: Remaja Rosdakarya.

Oesman, Oetojo. 1993. Pancasila Sebagai Ideologi. Jakarta : Perum Percetakan Negara RI.

Slameto. 2010. Belajar dan Faktor-faktor yang Mempengaruhinya. Jakarta : Rineka Cipta Sudjana. 2008. Metodologi Penelitian. Jakarta: Bumi Aksara Sugiyono. 2008. Model Penelitian. Bandung: Alphabeta Sumantri, Surya. 2000. Penelitian Kependidikan, Prosedur dan Strategi. Bandung: Angkasa. 